\title{
Case Report: Colchicine Overdose in a Suicidal Attempt
}

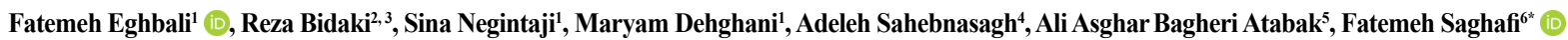

1. Student Research Committee, School of Pharmacy, Shahid Sadoughi University of Medical Sciences, Yazd, Iran.

2. Department of Psychiatry, School of Medicine, Research Center of Addiction and Behavioral Sciences, Shahid Sadoughi University of Medical Sciences and Health Services, Yazd, Iran.

3. Diabetes Research Center, Shahid Sadoughi University of Medical Sciences and Health Services, Yazd, Iran.

4. Department of Internal Medicine, School of Medicine, Imam Ali Hospital, North Khorasan University of Medical Sciences, Bojnurd, Iran.

5. Department of Medical Student, School of Medicine, Shahid Sadoughi University of Medical Sciences and Health Services, Yazd, Iran.

6. Department of Clinical Pharmacy, Faculty of Pharmacy and Pharmaceutical Sciences Research Center, Shahid Sadoughi University of Medical Sciences, Yazd, Iran.

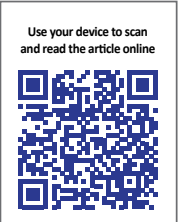

Citation: Eghbali F, Bidaki R, Negintaji S, Dehghani M, Sahebnasagh A, Bagheri Atabak AA, et al. Colchicine Overdose in a Suicidal Attempt. International Journal of Medical Toxicology and Forensic Medicine. 2019; 9(4):265-270. https://doi. org/10.32598/ijmtfm.v9i4.26520

https://doi.org/10.32598/ijmtfm.v9i4.26520

\section{(c) (1) (s)}

Article info:

Received: 17 Mar 2019

First Revision: 05 Apr 2019

Accepted: 10 Aug 2019

Published: 01 Oct 2019

\section{Keywords:}

Colchicine, Toxicity, Case

\begin{abstract}
Colchicine overdose is uncommon; however, it can cause serious adverse effects and even death. Colchicine inhibits microtubule polymerization, causing mitotic spindle disruption. Ingesting $>0.5 \mathrm{mg}$ of colchicine per kilogram bodyweight causes severe adverse effects and can even be fatal. Therefore, colchicine toxicity must be accurately monitored and managed.

In this case report, we described a 21-year-old woman who attempted suicide by the ingestion of an estimated $30 \mathrm{mg}$ colchicine. She was admitted to the hospital due to severe abdominal and chest pain, vomiting, lethargy, and weakness. The patient was medicated with ondansetron, apotel, antibiotics, platelet transfusions, sodium phosphate, calcium gluconate, calcitriol, desmopressin acetate, Granulocyte-Colony Stimulating Factor (G-CSF), and sodium bicarbonate. Fortunately, through the appropriate medical treatment, the signs and symptoms of colchicine toxicity were relieved and the patient survived despite the high colchicine serum level.
\end{abstract}

\section{Introduction}

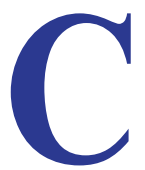

olchicine is a neutral and lipophilic alkaloid extracted from the autumn crocus (colchicum autumnale), i.e. an old wellknown drug. The United States Food and Drug Administration (FDA) approved the brand-name colchicine product (Colcrys) in 2009.
However, colchicine's medicinal properties have been recognized for centuries [1]. Even before FDA approval, it had extensive range of clinical uses from gout and familial Mediterranean fever to a variety of rheumatologic and cardiovascular indications, sarcoidosis, and psoriasis. The anti-inflammatory effects of colchicine are preventing activation, degranulation, and the migration of

* Corresponding Author:

Fatemeh Saghafi, PhD.

Address: Department of Clinical Pharmacy, Faculty of Pharmacy, Shahid Sadoughi University of Medical Sciences, Yazd, Iran. Tel: +98 (913) 2733898

E-mail: saghafifa@gmail.com 
neutrophils. In addition, colchicine inhibits the deposition of uric acid crystals and mitosis [1-3].

The initial symptoms of colchicine toxicity include abdominal cramps, diarrhea, nausea, and vomiting. Colchicine toxicity may also result in delayed symptoms, such as seizures, cardiac dysrhythmias, hypotension, shock, pancytopenia, and respiratory, as well as renal and hepatic failure [4].

Colchicine preferentially binds three proteins; tubulin, cytochrome P450 3A4 (CYP3A4), and P-glycoprotein (P-gp). The dissociation half-life of colchicine from tubulin is $20-40$ hours, which primarily defines colchicine's long clinical half-life [5]. The volume of distribution and total body clearance of colchicine significantly reduce the fallowing of its high doses leading to a higher plasma concentration and greater toxicity risk [6].

In this case report, we described a 21-year-old woman who attempted suicide by ingesting an estimated $30 \mathrm{mg}$ of colchicine.

\section{Case Report}

We investigate a 21-year-old unmarried woman (height: 63 inches; weight: $52 \mathrm{~kg}$ ) who attempted suicide by ingesting 30 of her mother's colchicine tablets due to family problems. She was admitted to the shahid Beheshti Hospital, Taft City, Iran. She presented complains of severe abdominal and chest pain, vomiting, lethargy, weakness, and agitation. She was admitted to the Cardiac Care Unit (CCU) due to the lack of an Intensive Care Unit (ICU) bed.

Previously, she was a healthy woman who used no medication or alcohol. The patient also had no prior history of mental disorders. Physical examinations revealed multiple wounds on her body, which were related to self-harming behavior.

Her father was a military veteran who has been exposed to chemical warfare agents during the Iran-Iraq war. The patient's mother behaved aggressively with the hospital staff, and she was also suffering from Paranoid Personality Disorder (PPD). At the time of hospital admission, the patient was conscious and able to speak. She confessed that the ingestion of colchicine was a suicidal attempt. She was constantly inclined to leave the hospital.

At the time of admission to $\mathrm{CCU}$, the patient presented with a Glasgow Coma Scale (GCS) of 13. Her Blood Pressure (BP) was 120/75 mmHg, Plus Rate (PR) 71/ minute in sinus rhythm, core temperature (T) $37.1^{\circ} \mathrm{C}$, Respiratory Rate (RR) 14 and $\mathrm{O} 2$ Saturation (O2 sat) before and after the administration of oxygen therapy were $27 \%$ and $56 \%$, respectively.

During the first post-admission day, laboratory test results (Table 1) revealed colchicine-induced pancytopenia, neutropenia, and thrombocytopenia. Therefore, the patient was treated with Vitamin $\mathrm{K}$, nasal epinephrine and tranexamic acid, platelet and Fresh Frozen Plasma (FFP) transfusions for oral and nasal mucosal bleeding. In addition, G-CSF for neutropenia, ondansetron PRN for nausea vomiting, Apotel PRN if $\mathrm{T}>38^{\circ} \mathrm{C}$, intravenous ranitidine vial sodium bicarbonate for metabolic acidosis, N-Acetyl Cysteine (NAC), and bromhexine as mucolytic were administered.

By the third day of admission, the patient was transferred to ICU because of a Loss of Consciousness (LOC) and hepatic encephalopathy. Vital signs by the time of admission to ICU were as following: $\mathrm{BP}=120 / 70 \mathrm{mmHg}$, $\mathrm{PR}=110 /$ minute, $\mathrm{RR}=18, \mathrm{~T}=37.3^{\circ} \mathrm{C}$. The patient developed aspiration pneumonia and respiratory insufficiency due to Acute Respiratory Distress Syndrome (ARDS), therefore, she was intubated. Additionally, based on chest radiography and continuous fever, she was treated for 5 days with meropenem (2 gr/TDS, IV), vancomycin (1gr/BD) and cefepime (2gr/daily).

By the fifth day of admission, initial clinical examination revealed abdominal distension and ascites. Computed Tomography (CT) scan of the abdomen and pelvis revealed inflammation of the liver, spleen, and mesenteric arteries. Due to the laboratory test results (Table 1) and the patient's condition, no further emergency procedures were required.

Abnormal serum calcium and phosphate levels indicated hypocalcemia and hypophosphatemia; therefore, the patient was treated with calcium gluconate, phosphate sodium, and calcitriol. Polyuria was another complication that she experienced; therefore, volume adjustment and nasal desmopressin were prescribed. The patient also suffered from neuromyopathy as a frequent complication of colchicine adverse effects. On the 10th day, the patient was transferred from ICU to the internal ward, where she stayed until her discharge ( 5 days later).

During the treatment course at the hospital, the patient insisted on leaving against the expressed advice of the treating team. At the time of discharge, all laboratory results (Table 1) and clinical manifestations were nor- 
Table 1. The patient's laboratory results

\begin{tabular}{|c|c|c|c|c|c|c|}
\hline \multirow{2}{*}{$\begin{array}{c}\text { Days } \\
\text { Test }\end{array}$} & \multicolumn{2}{|c|}{ (CCU) } & \multicolumn{2}{|c|}{ (ICU) } & \multirow[b]{2}{*}{$\begin{array}{l}\text { Last } \\
\text { Day }\end{array}$} & \multirow[b]{2}{*}{ Reference Value } \\
\hline & $\begin{array}{c}1^{\text {st }} \\
\text { Day }\end{array}$ & $\begin{array}{l}2^{\text {nd }} \\
\text { Day }\end{array}$ & $\begin{array}{l}3^{\text {rd }} \\
\text { Day }\end{array}$ & $\begin{array}{c}5^{\text {th }} \\
\text { Day }\end{array}$ & & \\
\hline WBC & $\begin{array}{c}3 \\
\text { (low) }\end{array}$ & $\begin{array}{c}0.7 \\
\text { (low) }\end{array}$ & $\begin{array}{c}1.2 \\
\text { (low) }\end{array}$ & $\begin{array}{c}13.1 \\
\text { (high) }\end{array}$ & 9.8 & 3.5-10 UI \\
\hline Neutrophil & 80 & 80 & 40 & 86.4 & 67.6 & $40 \%-80 \%$ \\
\hline Lymphocyte & 16 & 20 & 60 & 6.5 & 21.7 & $20 \%-40 \%$ \\
\hline $\mathrm{Hgb}$ & $\begin{array}{c}10.2 \\
\text { (low) }\end{array}$ & $\begin{array}{c}9.3 \\
\text { (low) }\end{array}$ & $\begin{array}{c}7.6 \\
\text { (low) }\end{array}$ & $\begin{array}{c}8.6 \\
\text { (low) }\end{array}$ & $\begin{array}{c}9.3 \\
\text { (low) }\end{array}$ & $11.5-18.8 \mathrm{gr} / \mathrm{dL}$ \\
\hline $\mathrm{HCT}$ & $\begin{array}{c}30.8 \\
\text { (low) }\end{array}$ & $\begin{array}{c}27.6 \\
\text { (low) }\end{array}$ & $\begin{array}{c}24.4 \\
\text { (low) }\end{array}$ & $\begin{array}{l}26.5 \\
\text { (low) }\end{array}$ & $\begin{array}{l}29.5 \\
\text { (low) }\end{array}$ & $34 \%-54 \%$ \\
\hline $\mathrm{MCV}$ & $\begin{array}{l}66.96 \\
\text { (low) }\end{array}$ & $\begin{array}{l}67.32 \\
\text { (low) }\end{array}$ & $\begin{array}{l}67.78 \\
\text { (low) }\end{array}$ & $\begin{array}{l}69.74 \\
\text { (low) }\end{array}$ & $\begin{array}{l}74.87 \\
\text { (low) }\end{array}$ & $80-96 \mathrm{flit}$ \\
\hline $\mathrm{MCH}$ & $\begin{array}{l}22.17 \\
\text { (low) }\end{array}$ & $\begin{array}{l}22.68 \\
\text { (low) }\end{array}$ & $\begin{array}{l}21.11 \\
\text { (low) }\end{array}$ & $\begin{array}{l}22.63 \\
\text { (low) }\end{array}$ & $\begin{array}{l}23.85 \\
\text { (low) }\end{array}$ & $24-36 \mathrm{pg}$ \\
\hline $\mathrm{MCHC}$ & 33.12 & 33.7 & $\begin{array}{l}31.15 \\
\text { (low) }\end{array}$ & $\begin{array}{l}32.45 \\
\text { (low) }\end{array}$ & $\begin{array}{l}31.85 \\
\text { (low) }\end{array}$ & $33-36 \%$ \\
\hline PLT & $\begin{array}{c}32 \\
\text { (low) }\end{array}$ & $\begin{array}{c}20 \\
\text { (low) }\end{array}$ & $\begin{array}{c}87 \\
\text { (low) }\end{array}$ & $\begin{array}{c}93 \\
\text { (low) }\end{array}$ & 302 & $150-450 \times 10^{\wedge} 3 / \mu \mathrm{L}$ \\
\hline PTT & 30 & 35 & 44 & 55 & - & $25-35 \mathrm{sec}$ \\
\hline PT & 15 & 12 & 12 & 13.7 & - & $12-14 \mathrm{sec}$ \\
\hline INR & 1.5 & 2.1 & 1.4 & 1.3 & - & $2.0-3.0$ \\
\hline FBS & 184 & 93 & 179 & 148 & 94 & $70-110$ \\
\hline $\mathrm{Cr}$ & $\begin{array}{c}0.56 \\
\text { (low) }\end{array}$ & $\begin{array}{c}0.46 \\
\text { (low) }\end{array}$ & $\begin{array}{c}0.45 \\
\text { (low) }\end{array}$ & $\begin{array}{c}0.44 \\
\text { (low) }\end{array}$ & 0.60 & $\mathrm{~F}: 0.6-1.3 \mathrm{mg} / \mathrm{dL}$ \\
\hline Bilirubin Total & $\begin{array}{c}1.7 \\
\text { (high) }\end{array}$ & $\begin{array}{c}2.1 \\
\text { (high) }\end{array}$ & $\begin{array}{c}1.5 \\
\text { (high) }\end{array}$ & $\begin{array}{c}4.2 \\
\text { (high) }\end{array}$ & - & $0.1-1.2 \mathrm{mg} / \mathrm{dL}$ \\
\hline Bilirubin Direct & $\begin{array}{c}0.6 \\
\text { (high) }\end{array}$ & $\begin{array}{c}1.0 \\
\text { (high) }\end{array}$ & $\begin{array}{c}0.9 \\
\text { (high) }\end{array}$ & $\begin{array}{c}1.2 \\
\text { (high) }\end{array}$ & - & $<0.3 \mathrm{mg} / \mathrm{dL}$ \\
\hline ALT & $\begin{array}{l}1150 \\
\text { (high) }\end{array}$ & $\begin{array}{c}1184 \\
\text { (high) }\end{array}$ & $\begin{array}{c}780 \\
\text { (high) }\end{array}$ & $\begin{array}{c}273 \\
\text { (high) }\end{array}$ & - & $F:<31 \mathrm{u} / \mathrm{L}$ \\
\hline AST & $\begin{array}{l}2664 \\
\text { (high) }\end{array}$ & $\begin{array}{l}2772 \\
\text { (high) }\end{array}$ & $\begin{array}{c}438 \\
\text { (high) }\end{array}$ & $\begin{array}{c}78 \\
\text { (high) }\end{array}$ & - & $5-50 \mathrm{uL}$ \\
\hline ALP & $\begin{array}{c}329 \\
\text { (high) }\end{array}$ & 227 & 148 & 146 & - & $F: 64-306 \mathrm{u} / \mathrm{L}$ \\
\hline $\mathrm{LDH}$ & $\begin{array}{l}15874 \\
\text { (high) }\end{array}$ & $\begin{array}{l}13740 \\
\text { (high) }\end{array}$ & $\begin{array}{c}3039 \\
\text { (high) }\end{array}$ & $\begin{array}{c}1222 \\
\text { (high) }\end{array}$ & - & Adult: $<500$ \\
\hline CPK & $\begin{array}{l}5437 \\
\text { (high) }\end{array}$ & $\begin{array}{l}12421 \\
\text { (high) }\end{array}$ & $\begin{array}{l}5106 \\
\text { (high) }\end{array}$ & $\begin{array}{c}386 \\
\text { (high) }\end{array}$ & - & $\mathrm{F}<170 \mathrm{u} / \mathrm{L}$ \\
\hline $\mathrm{Na}$ & 137 & $\begin{array}{c}134 \\
\text { (low) }\end{array}$ & 136 & 140 & 135 & $134-145 \mathrm{mEq} / \mathrm{L}$ \\
\hline $\mathrm{K}$ & 3.7 & 3.6 & 4.1 & $\begin{array}{c}3.4 \\
\text { (low) }\end{array}$ & 4.4 & 3.5-5.5 mEq/L \\
\hline $\mathrm{Ca}$ & - & - & $\begin{array}{c}7.2 \\
\text { (low) }\end{array}$ & $\begin{array}{c}7.7 \\
\text { (low) }\end{array}$ & $\begin{array}{c}10.7 \\
\text { (high) }\end{array}$ & $8.6-10.3 \mathrm{mg} / \mathrm{dL}$ \\
\hline $\mathrm{P}$ & - & - & - & $\begin{array}{c}1.9 \\
(\text { low) }\end{array}$ & 6.4 & $3.9-7.7 \mathrm{mg} / \mathrm{dL}$ \\
\hline
\end{tabular}


mal, except for the pulse rate of $120 / \mathrm{min}$, which revealed tachycardia.

\section{Discussion}

Colchicine is a neutral lipophilic alkaloid from the plant Colchicum autumnale (autumn crocus, meadow saffron) and Gloriosa superba (glory lily) [7]. Colchicine is prescribed in Iran for gout (acute and prophylaxis) and Familial Mediterranean Fever (FMF). This drug has a narrow therapeutic index, which means small differences in the dose or blood concentration of colchicine may lead to therapeutic failures or adverse drug reactions. There is no antidote for colchicine toxicity; therefore, prevention is a crucial factor in avoiding colchicine toxicity and death $[7,8]$.

Colchicine is readily absorbed after oral administration; however, it undergoes extensive first-pass metabolism. Colchicine is primarily eliminated by hepatic metabolism which involves de-acetylation and de-methylation, followed by biliary excretion. In addition, renal excretion also accounts for $10 \%-20 \%$ of colchicine removal [9].

In a therapeutic dose, the protein binding of colchicine is $10 \%-50 \%$, and the Volume of Distribution (VD) ranges between 2 and $12 \mathrm{~L} / \mathrm{kg}$, which reaches up to $21 \mathrm{~L} / \mathrm{kg}$ in the overdose of colchicine [5].

The most common adverse effects of colchicine are Gastrointestinal (GI) symptoms, which include nausea, vomiting, and particularly diarrhea, occurring in 5\%$10 \%$ of patients even at the recommended doses. The colchicine doses of 0.5 to $0.8 \mathrm{mg} / \mathrm{kg}$ are highly toxic, and doses of $>0.8 \mathrm{mg} / \mathrm{kg}$ are typically lethal [10].

Acute colchicine toxicity is described in three phases. The first phase presents with GI symptoms in the first 24 hours; abdominal pain, nausea, vomiting, and diarrhea. In addition, dehydration and leukocytosis may also occur. The second phase develops 24-72 hours post-ingestion and is associated with mononeuropathy and multiorgan failure. If the patient survives the second phase, transient alopecia and a rebound leukocytosis may occur in the third phase. Neuromyopathy, cytopenias (especially thrombocytopenia), and elevated Creatine Phosphokinase (CPK) level are classic features associated with chronic colchicine toxicity $[1,2,11-15]$.

Ingesting $>0.5 \mathrm{mg}$ of colchicine per kilogram bodyweight causes serious adverse effects and can even be fatal. In this case report, the patient ingested $30 \mathrm{mg}$ of colchicine, which was more than $0.5 \mathrm{mg} / \mathrm{kg}$. Family conflicts had a significant role in her suicide attempt. The patient's mother was suffering from PPD. Even though the patient was hospitalized because of an apparent drug overdose, her mother had the illusion that physicians have transferred her daughter to ICU to charge them extra money. She even claimed that the healthcare staffs of hospital want to transplant her daughter's kidney and uterus to another person.

Furthermore, the patient's family was non-cooperative with treatment and the healthcare staff. The major hematologic manifestations of patient were bone pancytopenia due to bone marrow suppression, which usually occurs on day 3 to 5 post-exposure. Serum liver enzymes, such as Aspartate Aminotransferase (AST), Alanine Aminotransferase (ALT), Alkaline Phosphatase (ALP), Lactate Dehydrogenase (LDH), and Creatine Phosphokinase (CPK) were significantly elevated due to hepatic encephalopathy. G-CSF and platelets were used to treat neutropenia and thrombocytopenia, respectively. Fortunately, White Blood Cell (WBC) count increased and became normal after 5 days of admission.

On the seventh day of admission, the platelet count, CPK, and ALP levels were within normal limits; while the LDH level was still high. The patient was discharged in a stable clinical condition after 17 days of hospitalization with scheduled follow-up appointments.

Deaths from colchicine overdoses generally result from multi-organ failure. Early diagnosis and treatment of colchicine intoxication can help in the management of symptoms and the reduction of mortality rate. Fortunately, in this case, through the appropriate medical treatment, the patient survived despite high colchicine toxicity.

\section{Conclusion}

Colchicine intoxication is a severe, life-threatening condition that should be followed accurately in ICUs. Severe body function changes can rapidly develop, which could be responsible for high mortality with acute complications. Nevertheless, this patient was able to survive against the dangerous and fatal complications of colchicine overdose. This patient was a unique case due to the displayed characteristics, which were severe bone marrow suppression, profound hypophosphatemia, and hypocalcemia, requiring intensive electrolyte and for having an unfavorable family situation. 


\section{Ethical Considerations}

\section{Compliance with ethical guidelines}

Ethical approval was obtained from Department of Forensic Medicine, School of Medicine, Shahid Sadoughi University of Medical Sciences, Iran.

\section{Funding}

The authors received no financial involvement for the research, author-ship and/or publication of this article.

\section{Author's contributions}

Analysing and interpreting the patient case: Reza Bidaki, Adeleh Sahebnasagh, Ali Asghar Bagheri Atabak, SNT; Writing the manuscript: Fatemeh Eghbali and Maryam Dehghani; Providing overall guidance in the conception and development of the study and approving the manuscript: Reza Bidaki and Fatemeh Saghaf; Reading and approving the final version of the manuscript: All authors.

\section{Conflict of interest}

The authors declare no potential conflicts of interest with respect to the research, authorship and/or publication of this case report.

\section{Acknowledgements}

The authors would like to gratefully thank the nursing personnel of the Psychiatric center of Yazd for their help.

\section{References}

[1] Rudolph SA, Greengard P, Malawista SE. Effects of colchicine on cyclic AMP levels in human leukocytes. Proceedings of the National Academy of Sciences of the United States of America. 1977; 74(8):3404-8. [DOI:10.1073/pnas.74.8.3404] [PMID] [PMCID]

[2] Lev S, Snyder D, Azran C, Zolotarsky V, Dahan A. Severe hypertriglyceridemia and colchicine intoxication following suicide attempt. Drug Design, Development and Therapy. 2017; 11:3321-4. [DOI:10.2147/DDDT.S140574] [PMID] [PMCID]

[3] Polat E, Tuygun N, Akca H, Karacan CD. Evaluation of the colchicine poisoning cases in a pediatric intensive care unit Five year study. The Journal of Emergency Medicine. 2017; 52(4):499-503. [DOI:10.1016/j.jemermed.2016.08.019] [PMID]

[4] Wasserscheid K, Backendorf A, Michna D, Mallmann R, Hoffmann B. Long-term outcome after suicidal colchicine intoxication in a 14-year-old girl: Case report and review of literature. Pediatric Emergency Care. 2013; 29(1):89-92. [DOI:10.1097/PEC.0b013e31827b5747] [PMID]

[5] Niel E, Scherrmann JM. Colchicine today. Joint, Bone, Spine. 2006; 73(6):672-8. [DOI:10.1016/j.jbspin.2006.03.006] [PMID]

[6] Rochdi M, Sabouraud A, Girre C, Venet R, Scherrmann JM. Pharmacokinetics and absolute bioavailability of colchicine after i.v. and oral administration in healthy human volunteers and elderly subjects. European Journal of Clinical Pharmacology. 1994; 46(4):351-4. [DOI:10.1007/BF00194404] [PMID]

[7] Link LH, Bindels AJ, Brassé BP, Intven FA, Grouls RJ, Roos AN. Severe colchicine intoxication; always lethal?!? Netherlands Journal of Critical Care. 2014; 18(4):19-21.

[8] Aghabiklooei A, Zamani N, Hassanian-Moghaddam $\mathrm{H}$, Nasouhi S, Mashayekhian MJR. Acute colchicine overdose: Report of three cases. Reumatismo. 2013; 65(6):307-11. [DOI:10.4081/reumatismo.2013.720] [PMID]

[9] Finkelstein $Y$, Aks SE, Hutson JR, Juurlink DN, Nguyen P, Dubnov-Raz G, et al. Colchicine poisoning: The dark side of an ancient drug. Clinical Toxicology. 2010; 48(5):407-14. [DOI: 10.3109/15563650.2010.495348] [PMID]

[10] Verne GN, Davis RH, Robinson ME, Gordon JM, Eaker EY, Sninksy CA. Treatment of chronic constipation with colchicine: randomized, double-blind, placebo-controlled, crossover trial. The American Journal of Gastroenterology. 2003; 98(5):1112-6. [DOI:10.1111/j.1572-0241.2003.07417.x] [PMID]

[11] Yousuf Bhat Z, Reddy S, Pillai U, Doshi M, Wilpula E. Colchicine-Induced Myopathy in a Tacrolimus-Treated Renal Transplant Recipient: Case Report and Literature Review. American Journal of Therapeutics. 2016; 23(2):e614-6. [DOI:10.1097/MJT.0000000000000044] [PMID]

[12] Mullins ME, Mullins M, Carrico EA, Horowitz BZ. Fatal cardiovascular collapse following acute colchicine ingestion. Journal of Toxicology: Clinical Toxicology. 2000; 38(1):51-4 [DOI:10.1081/CLT-100100916] [PMID]

[13] Paschke S, Weidner AF, Paust T, Marti O, Beil M, Ben-Chetrit E. Technical advance: Inhibition of neutrophil chemotaxis by colchicine is modulated through viscoelastic properties of subcellular compartments. Journal of Leukocyte Biology. 2013; 94(5):1091-6. [DOI:10.1189/jlb.1012510] [PMID]

[14] Robert A, Terkeltaub RA. Colchicine update. Seminars in Arthritis and Rheumatism. 2009; 38(6):411-9. [DOI:10.1016/j. semarthrit.2008.08.006] [PMID]

[15] Cronstein BN, Molad Y, Reibman J, Balakhane E, Levin RI, Weissmann G. Colchicine alters the quantitative and qualitative display of selectins on endothelial cells and neutrophils. The Journal of Clinical Investigation. 1995; 96(2):994-1002. [DOI:10.1172/JCI118147] [PMID] [PMCID] 
This Page Intentionally Left Blank 